\title{
Atypical eye complication in Takayasu's arteritis
}

\section{Puneet Mashru, Parikshit Sagdeo, Yathish Gattimallanahali, Gurmeet Mangat}

Department of Rheumatology, PD Hinduja Hospital and Medical Research Centre, Mumbai, Maharashtra, India

\section{Correspondence to} Dr Yathish Gattimallanahali, yathish_gc@yahoo.co.in

Accepted 22 May 2016

\section{DESCRIPTION}

A 31-year-old woman reported of left lower limb claudication and low-grade fever for 2 months. Examination showed asymmetry of upper limb blood pressure, carotid bruit, absent left dorsalis pedis and carotidynia. Systemic examination was normal. The patient was non-obese and a non- smoker, with no history of hypertension, diabetes mellitus, hypercholesterolaemia, coronary artery disease, rheumatic heart disease or cerebrovascular disease. Her family history was unremarkable. CT angiogram (figure 1) showed diffuse wall thickening of the ascending aorta and arch of the aorta, and stenosis and dilation of the aortic arch

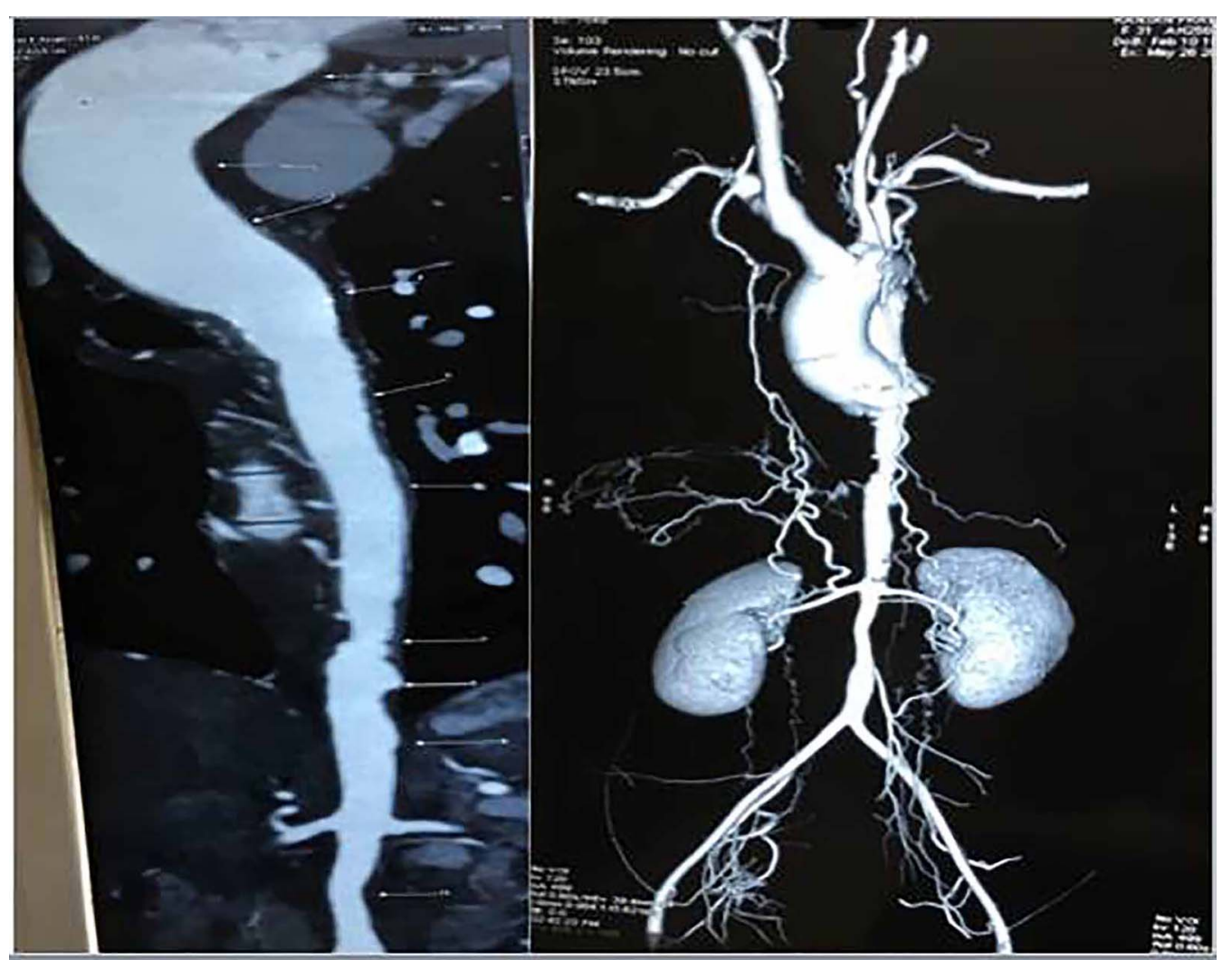

Figure $1 \mathrm{CT}$ angiogram showing diffuse wall thickening, irregularity and dilation of the abdominal aorta.

\section{BEFORE TREATMENT}
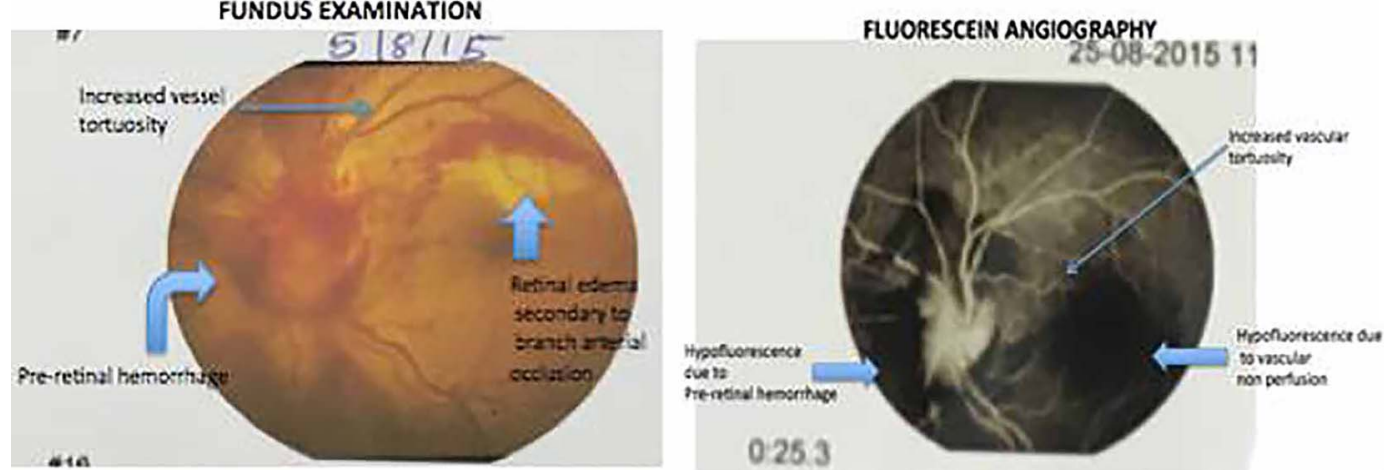

Figure 2 Fundus examination and fluorescein angiography showing retinal oedema secondary to branch retinal arterial occlusion. 


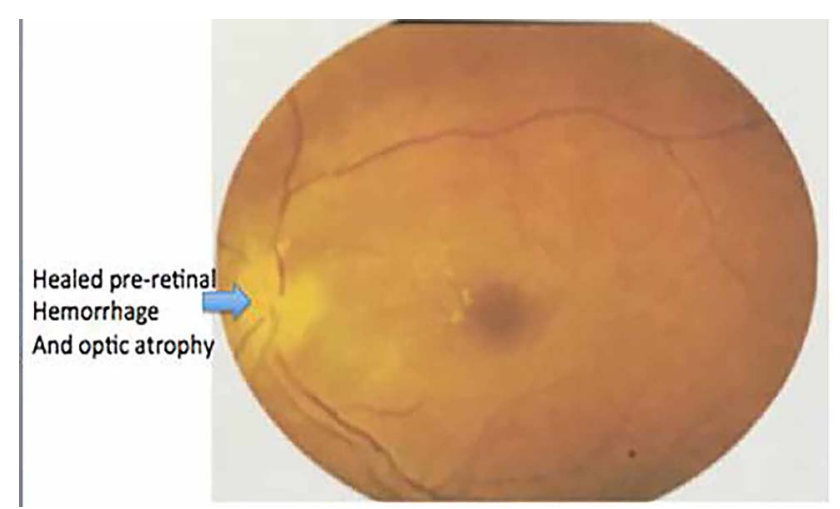

Figure 3 Fundus examination showing healed preretinal haemorrhage and optic atrophy.

branches, and descending and abdominal aorta. Four of the six diagnostic criteria of Takayasu's arteritis (according to American College of Rheumatology 1990 classification criteria) were present and thus we treated the patient with methotrexate $15 \mathrm{mg}$ weekly and a tapering dose of prednisolone $0.5 \mathrm{mg} / \mathrm{kg} /$ day. She presented 4 months later with acute onset decreased left eye vision while still on treatment. She had history of neither drug use nor prior visual disturbances. Her visual acuity in the left eye was finger counting at $3 \mathrm{~m}$ while the right eye was 20/20. An ophthalmology consult diagnosed the patient as having branch retinal arterial occlusion, based on fundus findings (figure 2). Her laboratory investigations showed normal fasting sugar and lipid profile, and her antiphospholipid antibodies were negative. She was treated immediately with prednisolone $1 \mathrm{mg} / \mathrm{kg} /$ day, tapered over 2 months to a maintenance dose of $5 \mathrm{mg} /$ day, with which she improved (figure 3). Her visual acuity at last follow-up improved to 20/60.

\section{DISCUSSION}

Takayasu's arteritis (TA) is a large vessel vasculitis. The involvement of small vessels, such as retinal vessels, is very rare. A review of cases, in 2013, by Noel et al, ${ }^{1}$ described seven cases of branch retinal artery occlusion and two cases of branch retinal vein occlusion reported in the literature. Four cases were inaugural of the disease. Type V TA was present in five of nine patients presenting with retinal vessel involvement, similar to that seen in our case. Immunosuppressive therapy benefited five patients while one showed stabilisation. Our patient improved with immunosuppression.

\section{Learning points}

Small retinal arterial involvement is a rare manifestation in Takayasu's arteritis.

- It may be an inaugural symptom in Takayasu's arteritis.

- Immunosuppression is beneficial.

Twitter Follow Yathish Gattimallanahali at @yathishgc45

Competing interests None declared.

Patient consent Obtained.

Provenance and peer review Not commissioned; externally peer reviewed.

\section{REFERENCE}

1 Noel N, Butel N, Le Hoang P, et al. Small vessel involvement in Takayasu's arteritis. Autoimmun Rev 2013;12:355-62.

Copyright 2016 BMJ Publishing Group. All rights reserved. For permission to reuse any of this content visit

http://group.bmj.com/group/rights-licensing/permissions.

BMJ Case Report Fellows may re-use this article for personal use and teaching without any further permission.

Become a Fellow of BMJ Case Reports today and you can:

- Submit as many cases as you like

- Enjoy fast sympathetic peer review and rapid publication of accepted articles

- Access all the published articles

- Re-use any of the published material for personal use and teaching without further permission

For information on Institutional Fellowships contact consortiasales@bmjgroup.com

Visit casereports.bmj.com for more articles like this and to become a Fellow 